(c) American Dairy Science Association, 2007.

\title{
The Profitability of Automatic Milking on Dutch Dairy Farms
}

\author{
R. Bijl, ${ }^{*}$ S. R. Kooistra, $†$ and H. Hogeveen* $\ddagger^{1}$ \\ ${ }^{*}$ Chair of Business Economics, Social Sciences Group, Wageningen University, Wageningen, the Netherlands \\ †Alfa Accountants en Adviseurs, Wageningen, the Netherlands \\ ‡Department of Farm Animal Health, Faculty of Veterinary Medicine, Utrecht University, Utrecht, the Netherlands
}

\begin{abstract}
Several studies have reported on the profitability of automatic milking based on different simulation models, but a data-based study using actual farm data has been lacking. The objective of this study was to analyze the profitability of dairy farms having an automatic milking system (AMS) compared with farms using a conventional milking system (CMS) based on real accounting data. In total, 62 farms (31 using an AMS and 31 using a CMS) were analyzed for the year 2003 in a case control study. Differences between the years 2002 and 2003 also were analyzed by comparing a subgroup of 16 farms with an AMS and 16 farms with a CMS. Matching was based on the time of investment in a milking system (same year), the total milk production per year, and intensity of land use (kg/ha). Results from 2003 showed that the farms with an AMS used, on average, 29\% less labor than farms with a CMS. In contrast, farms using a CMS grew faster $(37,132 \mathrm{~kg}$ of milk quota and 5 dairy cows) than farms with an AMS (-3,756 kg milk quota and 0.5 dairy cows) between 2002 and 2003. Dairy farmers with a CMS had larger $(€ 7,899)$ revenues than those with an AMS. However, no difference in the margin on dairy production was detected, partly because of numerically greater $(€ 6,822)$ variable costs on CMS farms. Dairy farms were compared financially based on the amount of money that was available for rent, depreciation, interest, labor, and profit (RDILP). The CMS farms had more money $(€ 15,566)$ available for RDILP than the AMS farms. This difference was caused by larger fixed costs (excluding labor) for the AMS farms, larger contractor costs (€6,422), and larger costs for gas, water, and electricity $(€ 1,549)$. Differences in costs for contractors and for gas, water, and electricity were statistically significant. When expressed per full-time employee, AMS farms had greater revenues, margins, and gross margins per full-time employee than did CMS farms. This resulted in a substantially greater (but not statistically signifi-
\end{abstract}

Received September 13, 2005.

Accepted August 2, 2006.

${ }^{1}$ Corresponding author: henk.hogeveen@wur.nl cant) RDILP per full-time employee $(€ 12,953)$ for AMS farms compared with CMS farms. Depreciation and interest costs for automatic milking were not available but were calculated based on several assumptions. Assuming larger purchase costs and a shorter depreciation time for AMS than for CMS, costs for depreciation and interest were larger for AMS farms than for CMS farms. Larger fixed costs should be compensated for by the amount of labor that has become available after introducing the milking robot. Therefore, farm managers should decide whether the extra time acquired by automatic milking balances against the extra costs associated with an AMS.

Key words: automatic milking, economics, profitability

\section{INTRODUCTION}

In 1992, the first automatic milking systems (AMS) were installed in the Netherlands, with a primary goal of replacing labor. In 2004, more than 2,200 farms worldwide were using AMS (de Koning and Rodenburg, 2004). Today, the reasons for investing in an AMS can be divided into social and economic reasons. The most important social reasons for investing in an AMS are that they allow more free time, provide more flexibility, and require less heavy labor-in general, offering a better quality of life (Mathijs, 2004). The economic benefits of automatic milking are mainly the savings in labor and increased production per cow (Wade et al., 2004).

In a model study, labor savings by using an AMS were estimated to be $38 \%$ (Sonck, 1995). More recently, Mathijs (2004) conducted a survey among 107 farmers who had invested in an AMS and found, on average, $18 \%(17 \mathrm{~h} / \mathrm{wk})$ of savings in labor. On the other hand, van 't Land et al. (2000) concluded from different studies that labor savings depended on the management capacities of the farmer, and in some cases, introduction of an AMS led to increased labor. Wirtz et al. (2004) reported that milk production could increase up to $20 \%$ if cows were milked 3 times daily with an AMS, whereas Wade et al. (2004) found an average increase of only $2 \%$ after the introduction of an AMS. 
Several studies have been published on the economic consequences of automatic milking (Arendzen and van Scheppingen, 2000; Hyde and Engel, 2002; Rotz et al., 2003). With some exceptions, the general trend in these studies was that automatic milking has negative effects on the economic performance of the farm when compared with conventional milking. The results of these studies differed substantially. Wade et al. (2004) described a difference of more than $€ 16,000$ in labor income. Others (Dijkhuizen et al., 1997; Hyde and Engel, 2002) found a break-even point of $€ 140,000$ for a herd of 125 cows and $\$ 374,000$ for a herd of 120 cows, respectively, making automatic milking economically beneficial. The actual investment for Dijkhuizen et al. (1997) was larger than the calculated break-even points, making the investment in automatic milking not cost effective. The break-even value in the model of Hyde and Engel (2002) was above the costs of the units, indicating that the investment in automatic milking was cost effective. Armstrong and Daugherty (1997) stated that on large farms, a robotic system must sell for less than $\$ 21,000$ to compete with a conventional milking system (CMS). Rotz et al. (2003) reported losses in annual net return of $\$ 0$ to $300 /$ cow, depending on farm size. In the latter study, the economic life of an AMS and a CMS were assumed to be equal. Arendzen and van Scheppingen (2000) showed, for a farm with a milk quota of $1,000,000 \mathrm{~kg}$ of milk, that the room for investment in an AMS depended on a decreased labor requirement and an increased milk yield-a difference that could be up to $€ 189,091$ ( $0 \%$ decrease in labor and no increase in milk yield vs. $30 \%$ decrease in labor and $15 \%$ increase in milk yield).

The economic studies conducted to date have been based on normative models in which the advantages of automatic milking (labor savings and increased production) were compared with increased costs (depreciation, maintenance, and interest). Introduction of an AMS will not only change the milk production and labor requirements but those of the whole operational management (van Vugt, 2005). It is not possible to study this complete change in farm management in a model study. A study on the economic aspects of automatic milking based on actual farm data is still needed. Therefore, the objective of this study was to analyze the profitability of dairy farms with an AMS in comparison with farms using a CMS based on actual farm data.

\section{MATERIALS AND METHODS}

\section{Data}

Data for this study originated from a Dutch accounting agency (Alfa Accountants en Adviseurs, Wageningen, the Netherlands). This agency is one of the largest bookkeeping agencies in the Netherlands and has customers throughout the country.

A database of 1,400 dairy farms, which contained 57 farms with an AMS, was available for this research. Because not all data for 2004 were yet available, 2003 was used as the year of comparison. Adoption of an AMS is often accompanied by start-up problems; therefore, installation of the AMS must have occurred before 2003. Nine farms installed their AMS in 2003 or 2004 and had to be excluded for this reason. Two other farms were excluded because they used both an AMS and a CMS. Moreover, data from 5 farms were incomplete and incorrect (not verified by an auditor) and could not be used.

A case control method was used in this study. Each farm with an AMS was matched with a farm that had invested in a new CMS during the same year. Dairy farms with a CMS were selected out of the same database. Matching was based on the year of investment in a milking system, the total milk production per year (maximum difference of 10\%), and the intensity of land use (defined as milk production/ha, with a maximum difference of $1,000 \mathrm{~kg} / \mathrm{ha}$ ). Ten farms could not be matched based on the chosen criteria. This resulted in a total of 31 farms with an AMS (referred to as AMS31) and 31 farms with a CMS (referred to as CMS31) used in the study. The principal occupation of these farms was dairy production. On these 31 farms, 55 milking units were in use, an average of 1.77 milking units per farm. Twenty-seven farms (46 units) used a Lely Astronaut (Lely Industries NV, Maasland, the Netherlands), 2 farms (4 units) used a Delaval VMS (De Laval VMS, Tumba, Sweden), 1 farm (3 units) used a Zenith (Zenith GM BV, Emmeloord, the Netherlands), and 1 farm (2 units) used a Liberty (Liberty, Zutphen, the Netherlands).

Technical and financial data on the 62 farms (AMS31 and CMS31) were available for the year 2003. To monitor differences in performance over the years, data from previous years were used. Data from 2002 for 16 of the 31 farms with an AMS (referred to as AMS16) and the matching 16 farms with a CMS (referred to as CMS16) could be used. No 2001 data were available.

In total, 244 variables were analyzed in this study. Data on the structure of the farm (labor, land, and livestock) and on the dairy production (revenues, feed costs, livestock costs, and costs of land) were all specified. By using these data, the gross margin could be determined. The nonaccountable costs (costs not directly associated with cattle husbandry or land use, such as contractor costs; costs for gas, water, and electricity; and maintenance and insurance costs of the machinery, equipment, land, buildings, and installations) were used to calculate overall farm profitability. 
The most important variables are presented in this article.

The economic results of the 2 groups in absolute amounts were shown to give an indication of the total profitability. In addition to these absolute economic figures, the economic results were also expressed per $100 \mathrm{~kg}$ of ECM to reflect the performance of the farm relative to the farm size. The ECM value was used because in the Netherlands, the price of milk is based on the kilograms of fat and protein. The ECM value was calculated as follows (Hemmer et al., 2004):

$$
\mathrm{ECM}=[0.337+(0.116 \times \% \mathrm{~F})+(0.06 \times \% \mathrm{P})] \times \mathrm{M},
$$

where $\mathrm{M}$ is the true milk yield (in $\mathrm{kg}$ ), $\% \mathrm{~F}$ is the fat percentage, and $\% \mathrm{P}$ is the protein percentage.

The farms were financially compared based on the amount of money that was available for rent, depreciation, interest, labor, and profit (RDILP). The RDILP was calculated as the gross margin minus the total nonaccountable costs (excluding labor). Rent, depreciation, interest, and labor were regarded as fixed costs and were therefore excluded when judging the performance of the farm. The purchase cost of an AMS is known to be greater than the purchase cost of a CMS for the same size of farm. Because AMS have been commercially available since 1992 and the improvements during the past years have been considerable, no data exist to suggest the economic lifetime of an AMS in relation to the economic lifetime of a CMS. Because of the greater level of complexity of an AMS (more electronics and precision mechanics), most economic studies assume a shorter economic lifetime of an AMS than a CMS (Armstrong and Daugherty, 1997; Cooper and Parsons, 1999; Hyde and Engel, 2002). Larger purchase costs and a shorter depreciation time of the AMS would have a negative impact on the financial outcomes of AMS farms. Therefore, the RDILP should be a good indicator of the dairy farm performance. However, depreciation and interest costs differ between milking systems and are important in economic performance. Unfortunately, the costs for depreciation and interest could not be estimated based on the available data, because the available bookkeeping data were meant for fiscal use. The resulting estimates for depreciation and interest could therefore not be used for a business economic purpose. Moreover, because AMS have been available on commercial dairy farms since 1992, no good estimate of their depreciation time exists. Therefore, per farm, the depreciation and interest for milking equipment were calculated normatively (based on assumptions). For an AMS farm, the number of milking units on that farm was multiplied by the purchase costs of 1 AMS unit. The purchase costs of 1
AMS unit (including building costs) were assumed to be $€ 100,000$. For a CMS farm, the investment in a milking parlor (including building costs) was estimated using the following function:

$$
Y_{i}=65,500 \times \log _{e}\left(X_{i}\right)-225,000
$$

where, $Y_{\mathrm{i}}$ denotes the total costs (including the building costs) of a milking parlor for farm $i$, and $X_{i}$ denotes the herd size of farm i, with $40<\mathrm{X}_{\mathrm{i}}<200$.

The logarithmic function used gives credit for the decreasing marginal costs (euros per milking cow) of a milking parlor for increasing herd sizes. For an AMS and a CMS, salvage values of 10 and 5\%, respectively, of the purchase value were assumed. The economic lifetimes were assumed to be 10 and $15 \mathrm{yr}$, respectively, for an AMS and a CMS. An interest rate of $5 \%$ was used.

\section{Data Analysis}

A descriptive analysis was carried out by using SPSS 13.0 for Windows (SPSS, 2005). For all variables, the standard deviation of the mean was larger than 50\%, from which we concluded that none of the variables were normally distributed. To test the null hypothesis of no difference between AMS and CMS farms, a nonparametric test of 2 related samples, the 2-tailed Wilcoxon test, was used (Field, 2000). The 2-tailed Wilcoxon test calculates differences in matched pairs of observations. These calculated differences were ranked, based on the absolute values of the difference. The rank sums of the negative and positive differences were compared and used to determine the statistical significance of the difference between AMS and CMS farms. The AMS31 and CMS31 farms were analyzed for the year 2003. To monitor the development of the farms, the AMS16 and CMS16 farms were analyzed for the year 2002 and differences in the AMS16 between the years 2002 and 2003 and differences in the CMS16 between the years 2002 and 2003 were analyzed.

\section{RESULTS AND DISCUSSION}

\section{Study Design}

The year of investment in a milking system for a CMS farm was similar to the year of investment in a milking system for the comparable AMS farm. Table 1 shows the similarities in farm structure between the AMS and CMS farms in 2003. Total milk quota and land use did not differ between the AMS and CMS farms. However, the average milk quota of the farms was larger (almost $400,000 \mathrm{~kg}$ of milk) than the average milk production $(442,904 \mathrm{~kg}$ of milk per farm) in The 
Table 1. Average structure of 31 farms using an automatic milking system (AMS) and 31 farms using a conventional milking system (CMS) in 2003

\begin{tabular}{|c|c|c|c|}
\hline Item & AMS & CMS & $P$ \\
\hline Total land use, ha & 60.0 & 61.7 & 0.906 \\
\hline Pasture, ha & 44.29 & 48.96 & 0.170 \\
\hline Milk quota, kg & 828,761 & 853,620 & 0.196 \\
\hline No. of dairy cows & 105 & 110 & 0.681 \\
\hline Total labor FTE ${ }^{1}$ & 1.45 & 1.87 & 0.001 \\
\hline Entrepreneurial labor FTE & 1.07 & 1.62 & 0.001 \\
\hline Family member labor FTE & 0.19 & 0.07 & 0.024 \\
\hline Employee labor FTE & 0.19 & 0.18 & 0.737 \\
\hline Dairy cows/family $\mathrm{FTE}^{2}$ & 85 & 65 & 0.001 \\
\hline Milk/family FTE, kg & 674,642 & 508,017 & 0.001 \\
\hline $\mathrm{ECM}^{3} /$ family FTE, kg & 703,702 & 534,681 & 0.001 \\
\hline Dairy cows/total FTE & 74 & 59 & 0.001 \\
\hline Milk/total FTE, kg & 586,241 & 459,117 & 0.001 \\
\hline ECM/total FTE, kg & 611,493 & 483,215 & 0.001 \\
\hline Milk/cow, kg & 8,011 & 7,894 & 0.845 \\
\hline $\mathrm{ECM} / \mathrm{cow}, \mathrm{kg}$ & 8,361 & 8,298 & 0.938 \\
\hline
\end{tabular}

${ }^{1}$ FTE $=$ Full-time employee.

${ }^{2}$ Family FTE is the sum of entrepreneurial and family member FTE.

${ }^{3} \mathrm{ECM}=$ Fat- and protein-corrected milk.

Netherlands (CBS, 2003). These data indicate that farms investing in an AMS are not average farms.

We examined the performance of the farms only after investment. It would have been preferable to make a "before and after" analysis. In that way, the impact on farm results of investing in an AMS could have been monitored. Because data from the accounting agency were available for only the most recent years, a "before and after" analysis was not possible. By using a case control design, the differences between farms were made as small as possible. Therefore, the farms were comparable and the results would be useful. Selection of data was done very strictly. If maximum differences in the matching criteria had been broadened, the number of farms included in the study could have increased. However, it was more important to have correct matching data instead of a larger number of farms.

The data originated from only 1 accounting agency. Using data from more accounting agencies also would have increased the number of farms, making the research more reliable. The disadvantage of using different agencies was that each agency has its own way of accounting, thus making it more difficult to make a comparison.

\section{Structure of Farms}

Table 1 shows the structure of the farms used in the study. The total amount of labor, expressed as full-time employee (FTE) equivalents, was smaller $(P<0.001)$ on the AMS31 than on the CMS31 farms. Gustafsson (2004) found 19\% labor savings when using an AMS.
In our study, the AMS31 used, on average, 29\% less labor $(P<0.001)$ than the CMS31. Labor costs for external workers were expected to be smaller for the AMS31 because less labor should be needed. However, in our study the use of external workers was almost equal between the groups. This meant that less home labor was used. This was also shown by the costs for external workers: the AMS31 was $€ 7,982$ and the CMS31 was $€ 8,438$. In our definition, $1 \mathrm{FTE}$ of family labor equaled $2,540 \mathrm{~h}$ of labor (approximately $50 \mathrm{~h} / \mathrm{wk}$ ). One FTE of family labor is therefore not equal to 1 member of the family. When a member of the family works hard, he or she can work more than $2,540 \mathrm{~h} / \mathrm{yr}$. This family member often will be counted for $>1$ FTE. On average, 1,067 more $(P<0.001)$ hours of labor (approximately $20 \mathrm{~h} /$ wk) were required on the CMS31 than on the AMS31 farms. A hard-working family on a farm can compensate for this by working longer hours each day.

The range of the entrepreneurial FTE for the AMS31 (0.5 to 1.6) indicated that the majority of AMS farms were run by a single family, whereas the range for the CMS31 (1.0 to 2.5) indicated that some of the CMS31 farms were run by more than 1 family. This means that farm income must be divided. Because this information was not available, this can only be assumed.

As a consequence of less use of labor, the efficiency of the AMS31 was better. On farms with an AMS, more $(P<0.001)$ cows were held and more $(P<0.001)$ milk was produced by a single FTE, both for total FTE and for family FTE. No differences in milk production per cow were detected between the 2 types of farms. Although more cows per FTE were held on the AMS farms than on the CMS farms, average milk production per robot was 494,442 kg of milk. Because the capacity of 1 robot lies approximately between 600,000 and $750,000 \mathrm{~kg}$ of milk/yr (De Koning and Ouweltjes, 2000), the full capacity of the AMS on the farms in this study was not fully realized. For better economic results, it is important that the machine be used to its full capacity.

In Table 2, results of the AMS16 and CMS16 are shown, including differences between years. Between 2002 and 2003, the CMS16 farms grew, with greater $(P<0.01 ; 37,132 \mathrm{~kg})$ milk quotas and 5 more $(P<0.01)$ cows, compared with the growth of the AMS16. As a consequence of differences in the growth in milk quotas and dairy cows, the efficiency per FTE (total FTE as well as family FTE) also was greater $(P<0.01)$.

The growth of the CMS16 and the stability of the AMS16 might be explained by the fact that dairy farmers using a CMS were able to grow stepwise within the existing farm structure. Annual investments would be in terms of milk quotas, whereas the farmers using an AMS must make large investments to grow (e.g., an additional automatic milking unit and a large quota 
Table 2. Average structure of 16 farms having an automatic milking system (AMS) and 16 farms using a conventional milking system (CMS) in 2002 and differences in the structures of these farms between 2002 and 2003

\begin{tabular}{|c|c|c|c|c|c|c|}
\hline \multirow[b]{2}{*}{ Item } & \multicolumn{2}{|c|}{2002} & \multirow[b]{2}{*}{$P$} & \multicolumn{2}{|c|}{ Difference of $2003-2002$} & \multirow[b]{2}{*}{$P$} \\
\hline & AMS & CMS & & AMS & CMS & \\
\hline Total land use, ha & 56.63 & 54.94 & 0.679 & 1.33 & 0.70 & 0.701 \\
\hline Pasture, ha & 41.11 & 45.21 & 0.326 & 1.85 & 0.25 & 0.281 \\
\hline Milk quota, kg & 779,420 & 763,357 & 0.379 & $-3,756$ & 37,132 & 0.010 \\
\hline No. of dairy cows & 95.97 & 96.03 & 0.756 & 0.47 & 5.00 & 0.009 \\
\hline Total labor FTE ${ }^{1}$ & 1.44 & 1.83 & 0.11 & 0.01 & -0.07 & 0.078 \\
\hline Entrepreneurial labor FTE & 0.98 & 1.51 & 0.003 & 0.00 & -0.01 & 0.655 \\
\hline Family member labor FTE & 0.24 & 0.08 & 0.168 & 0.01 & -0.01 & 0.102 \\
\hline Employee labor FTE & 0.23 & 0.23 & 0.733 & 0.00 & -0.05 & 0.281 \\
\hline Dairy cows/family $\mathrm{FTE}^{2}$ & 79.39 & 60.45 & 0.013 & -0.76 & 20.06 & 0.003 \\
\hline Milk/family FTE, kg & 646,351 & 470,154 & 0.001 & $-7,409$ & 187,862 & 0.000 \\
\hline $\mathrm{ECM}^{3}$ /family FTE, kg & 683,697 & 484,632 & 0.002 & $-7,191$ & 192,577 & 0.000 \\
\hline Dairy cows/total FTE & 67.88 & 52.57 & 0.013 & -0.76 & 5.73 & 0.008 \\
\hline Milk/total FTE, kg & 553,942 & 399,854 & 0.001 & $-7,409$ & 53,675 & 0.004 \\
\hline ECM/total FTE, kg & 579,243 & 421,074 & 0.002 & $-7,191$ & 55,022 & 0.004 \\
\hline Milk/cow, kg & 8,249 & 7,711 & 0.255 & -24 & 214 & 0.148 \\
\hline $\mathrm{ECM} / \mathrm{cow}, \mathrm{kg}$ & 8,620 & 8,113 & 0.352 & -15 & 189 & 0.196 \\
\hline
\end{tabular}

${ }^{1} \mathrm{FTE}=$ Full-time employee.

${ }^{2}$ Family FTE is the sum of entrepreneurial and family member FTE.

${ }^{3} \mathrm{ECM}=$ Fat- and protein-corrected milk.

amount). However, on average, dairy farms in our study were not utilizing the full capacity of the milking units. This indicates that there is space to grow within the existing capacity of the AMS. Another explanation could be that the farmers using an AMS already grew substantially after introducing the milking unit (average of $4 \mathrm{yr}$ previously) and that farmers using a CMS were gradually catching up.

\section{Economic Results}

Descriptive Overview. Table 3 shows the averages and the 5th and 95th percentiles of revenues, costs, margins, nonaccountable costs, and RDILP. The calculation methods also are shown in this table. Differences between the systems are discussed later.

Dairy Production. Table 4 shows milk production on the AMS and CMS farms. The protein percentage was greater $(P<0.02)$ for farms using a CMS. Cows on the AMS31 were kept inside more often (van Vugt, 2005) and may have consumed less fresh, high-protein roughage. The ECM tended $(P=0.065)$ to be larger for the farms using a CMS. In Table 5, revenues, costs, and margins are given for the whole farm and are expressed per $100 \mathrm{~kg}$ of ECM. Because of the quota system and the greater prices of milk quotas in The Netherlands, the production capacity is made up by the milk quota. Milk payments are based on the amount of fat and protein delivered. To compare farms, the economic performance per $100 \mathrm{~kg}$ of ECM is important. A difference was shown in milk revenues (Table 5), both abso- lute $(P=0.003)$ and per $100 \mathrm{~kg}$ of $\operatorname{ECM}(P=0.002)$, between the AMS and CMS farms. The milk price was the same for the 2 farm types, but because of the larger protein and fat percentages, the ECM price was larger $(P=0.002)$ for the CMS31 farms. However, this difference was not expressed in the total revenues because of the numerically larger miscellaneous revenues of the AMS31. No difference was detected in costs. The margin on dairy production per $100 \mathrm{~kg}$ of ECM was nearly identical.

Growth of the CMS16 (monitored in Table 2) also is shown in Table 6 . The difference in milk revenues (absolute) between years was greater $(P<0.011)$ for the CMS16 than the AMS16 farms. Costs did not differ. As a consequence, no difference in the absolute margin on the dairy was detected. When looking at the differences in milk revenues per $100 \mathrm{~kg}$ of ECM between years, no differences were found. Both systems showed a decrease in milk revenues compared with the previous year. This can be explained by an average decrease in the milk price in the Netherlands of $€ 1.03$ per $100 \mathrm{~kg}$ of ECM (Alfa, 2004).

Profitability. Costs for contractors and costs for gas, water, and electricity were greater $(P<0.05)$ for farms with an AMS than for those using a CMS (Table 7). Under Dutch circumstances, the contractor costs consist mainly of costs accrued to hire contractors for such things as harvesting. The larger contractor costs on an AMS farm might be explained by a different feeding strategy on these farms. On farms with an AMS, cows are more often held inside near the milking unit (van 
BIJL ET AL.

Table 3. Average, 5th, and 95th percentiles of revenues, costs, margins, nonaccountable costs, and RDILP ${ }^{1}$ (all in euros) for 31 farms having an automatic milking system (AMS) and 31 farms using a conventional milking system (CMS) in 2003

\begin{tabular}{|c|c|c|c|c|c|c|}
\hline \multirow[b]{2}{*}{ Item } & \multicolumn{3}{|c|}{ AMS } & \multicolumn{3}{|c|}{ CMS } \\
\hline & Average & $\begin{array}{l}5 \text { th } \\
\text { percentile }\end{array}$ & $\begin{array}{l}95 \text { th } \\
\text { percentile }\end{array}$ & Average & $\begin{array}{l}5 \text { th } \\
\text { percentile }\end{array}$ & $\begin{array}{l}\text { 95th } \\
\text { percentile }\end{array}$ \\
\hline \multicolumn{7}{|l|}{ Revenues } \\
\hline Milk & 274,556 & 145,863 & 445,676 & 287,333 & 149,436 & 422,934 \\
\hline Payment milk quota surplus & $-1,013$ & $-6,011$ & 0 & -808 & $-2,372$ & 43 \\
\hline Milk quality penalties & -45 & 0 & 0 & -52 & -24 & 61 \\
\hline Livestock & 18,243 & 5,548 & 29,865 & 17,629 & $-3,131$ & 36,966 \\
\hline Miscellaneous & 7,506 & 133 & 21,531 & 3,046 & 0 & 14,782 \\
\hline Total (a) & 299,248 & 170,300 & 455,178 & 307,147 & 172,287 & 456,512 \\
\hline \multicolumn{7}{|l|}{ Feed costs } \\
\hline Concentrates & 40,718 & 20,316 & 68,686 & 44,057 & 22,152 & 71,548 \\
\hline Substitutes for concentrates & 5,519 & 0 & 10,631 & 6,734 & 0 & 21,045 \\
\hline Roughage & 3,414 & $-3,863$ & 11,223 & 3,081 & $-10,099$ & 14,570 \\
\hline Milk products & 1,651 & 0 & 3,600 & 1,838 & 0 & 6,569 \\
\hline Other feed & 2,901 & 201 & 7,220 & 1,410 & 114 & 4,185 \\
\hline Total (b) & 54,202 & 27,067 & 87,178 & 57,120 & 28,803 & 102,021 \\
\hline \multicolumn{7}{|l|}{ Livestock costs } \\
\hline Health & 4,526 & 1,311 & 10,937 & 5,135 & 1,548 & 11,245 \\
\hline Medicines & 3,036 & 0 & 7,932 & 3,078 & 0 & 8,542 \\
\hline $\mathrm{AI}$ and breeding & 5,136 & 561 & 12,034 & 7,871 & 3,318 & 20,415 \\
\hline Miscellaneous & 5,508 & 1,460 & 12,480 & 4,474 & 953 & 7,921 \\
\hline Total (c) & 18,205 & 6,460 & 32,230 & 20,559 & 8,742 & 36,804 \\
\hline \multicolumn{7}{|l|}{ Costs of land use } \\
\hline Fertilizer & 7,443 & 2,462 & 13,711 & 7,048 & 3,130 & 12,410 \\
\hline Seed & 1,991 & 0 & 6,595 & 3,699 & 336 & 9,465 \\
\hline Pesticide & 1,169 & 0 & 4,779 & 1,810 & 0 & 4,776 \\
\hline Miscellaneous & 794 & 0 & 1,768 & 391 & 0 & 1,040 \\
\hline Total (d) & 11,396 & 4,497 & 24,969 & 12,948 & 4,476 & 27,379 \\
\hline Total costs $(b+c+d)(e)$ & 83,804 & 40,249 & 131,645 & 90,626 & 47,982 & 152,808 \\
\hline \multicolumn{7}{|l|}{ Margins } \\
\hline Margin on dairy $(\mathrm{a}-\mathrm{e})$ & 215,444 & 118,937 & 337,370 & 216,521 & 124,513 & 321,746 \\
\hline Margin other farm activities & 3,286 & 0 & 14,638 & 2,651 & $-1,200$ & 14,866 \\
\hline Other activities & 12,813 & 0 & 41,302 & 13,347 & 779 & 37,173 \\
\hline Gross margin (f) & 231,542 & 123,731 & 364,341 & 232,519 & 127,639 & 336,610 \\
\hline \multicolumn{7}{|l|}{ Nonaccountable costs } \\
\hline Contractor & 21,783 & 5,653 & 44,862 & 15,361 & 3,369 & 28,597 \\
\hline \multicolumn{7}{|l|}{ Maintenance and insurance of: } \\
\hline Machinery and equipment & 28,088 & 10,705 & 52,718 & 24,411 & 8,172 & 48,126 \\
\hline Land, buildings, installations & 7,404 & 1,329 & 15,546 & 5,371 & -748 & 14,594 \\
\hline Gas, water, and electricity & 10,337 & 4,482 & 17,052 & 8,788 & 4,853 & 13,449 \\
\hline Other nonaccountable costs & 12,002 & 6,395 & 17,883 & 11,093 & 6,561 & 16,044 \\
\hline Total $(\mathrm{g})$ & 79,614 & 42,934 & 125,890 & 65,025 & 29,829 & 102,327 \\
\hline Available for RDILP $(f-g)$ & 151,928 & 80,073 & 262,962 & 167,494 & 82,627 & 249,811 \\
\hline
\end{tabular}

${ }^{1}$ Rent, depreciation, interest, labor, and profit.

Vugt, 2005). Additional work flowing out of this change of feeding strategy might be carried out partly by contractors. The 29\% lower labor requirement on AMS

Table 4. Average milk production, fat percentage, protein percentage, and ECM of 31 farms having an automatic milking system (AMS) and 31 farms using a conventional milking system (CMS) in 2003

\begin{tabular}{lccl}
\hline Item & AMS & \multicolumn{1}{l}{ CMS } & $P$ \\
\hline Milk production, kg/farm & 836,095 & 847,057 & 0.203 \\
Fat, \% & 4.33 & 4.37 & 0.264 \\
Protein, \% & 3.42 & 3.47 & 0.017 \\
ECM, kg/farm & 870,585 & 891,057 & 0.065 \\
\hline
\end{tabular}

farms (Table 1) might not necessarily be caused only by a reduced amount of labor for milking, but also could be caused by an increased use of contractors. For shortterm (tactical) decisions, the margins are an important factor to consider. For long-term (strategic) decisions, the overall profitability of a farm is important. The net result (profit) of a farm is used many times. Although this is true for a specific farm, the net result is dependent on the financial structure of a specific farm. Comparing farms on the basis of the net result might therefore actually be merely a comparison of farm structures and not of farm management. The RDILP is therefore 
Table 5. Average revenues, costs, and margins on dairy (in euros), absolute and per $100 \mathrm{~kg}$ of ECM, of 31 farms having an automatic milking system (AMS) and 31 farms using a conventional milking system (CMS) in 2003

\begin{tabular}{|c|c|c|c|c|c|c|}
\hline \multirow[b]{2}{*}{ Item } & \multicolumn{2}{|c|}{ Absolute } & \multirow[b]{2}{*}{$P$} & \multicolumn{2}{|c|}{$100 \mathrm{~kg}$ of ECM } & \multirow[b]{2}{*}{$P$} \\
\hline & AMS & CMS & & AMS & CMS & \\
\hline Milk revenues & 274,556 & 287,333 & 0.003 & 31.53 & 32.27 & 0.002 \\
\hline Miscellaneous revenues & 24,692 & 19,815 & 0.583 & 2.82 & 2.27 & 0.232 \\
\hline Total revenues & 299,248 & 307,147 & 0.112 & 34.35 & 34.54 & 0.544 \\
\hline Concentrate costs & 40,718 & 44,057 & 0.357 & 4.67 & 4.83 & 0.481 \\
\hline Total feed costs & 54,202 & 57,120 & 0.290 & 6.47 & 6.33 & 0.845 \\
\hline Health costs & 7,561 & 8,213 & 0.597 & 0.84 & 0.93 & 0.681 \\
\hline Total livestock costs & 18,205 & 20,559 & 0.468 & 2.01 & 2.25 & 0.531 \\
\hline Land use costs & 11,396 & 12,948 & 0.224 & 1.28 & 1.46 & 0.170 \\
\hline Total costs & 83,804 & 90,626 & 0.164 & 9.76 & 10.04 & 0.505 \\
\hline Margin dairy production & 215,444 & 216,521 & 0.597 & 24.60 & 24.50 & 0.953 \\
\hline
\end{tabular}

a good measure to estimate the overall profitability independent of the farm structure. The RDILP represents the benefits and those cost factors that are not necessarily expenses. The RDILP was larger $(P<0.05)$ by $€ 15,566$ for CMS31 farms, caused by the smaller nonaccountable costs of the CMS31. The same results were found per $100 \mathrm{~kg}$ of ECM. No differences between the years 2002 and 2003 were detected for the CMS16 and AMS16 farms (Table 8). As a result of the growth of the CMS16, the RDILP increased, whereas the RDILP decreased in the AMS16. Because of the lower milk price, both systems decreased in RDILP per $100 \mathrm{~kg}$ of ECM.

When the most important profitability factors are expressed per FTE (Table 9), one can see that the AMS farms had greater $(P<0.05)$ revenues, margins, and gross margins per FTE than the CMS farms. The AMS farms had a numerically greater RDILP per FTE $(€ 12,953)$ than the RDILP per FTE for the CMS farms. Because there was no difference in the use of external labor, this means that the farmers using an AMS do not save money by reducing external work, but increase their opportunity costs by reducing their own labor. This is a clear advantage of automatic milking that might differ from farm to farm, depending on the opportunity costs of labor on a specific farm, which might vary from 0 to $€ 21,840(1,092 \mathrm{~h}$ at $€ 20 / \mathrm{h})$. In our study, opportunity costs of labor were not known. On the other hand, these findings show that AMS makes it possible for family farms to increase in size (in terms of total milk production per year, number of dairy cows, or both) without hiring additional personnel.

The results shown so far do not account for depreciation and interest. For several reasons, the exact depreciation of AMS and CMS are not known. Because AMS have been available on the market only since 1992, no reliable estimate of their economic life span exists. Moreover, the depreciation that is available in the bookkeeping system is the fiscal depreciation. Because of the Dutch fiscal system, yearly depreciation is set as large as possible to be able to deduct as much as possible for taxes. Because depreciation and interest are im-

Table 6. Average revenues, costs, and margins on dairy production (in euros), absolute and per $100 \mathrm{~kg}$ of ECM, of 16 farms having an automatic milking system (AMS) and 16 farms using a conventional milking system (CMS) in 2002 and the differences in structure of these farms between 2002 and 2003

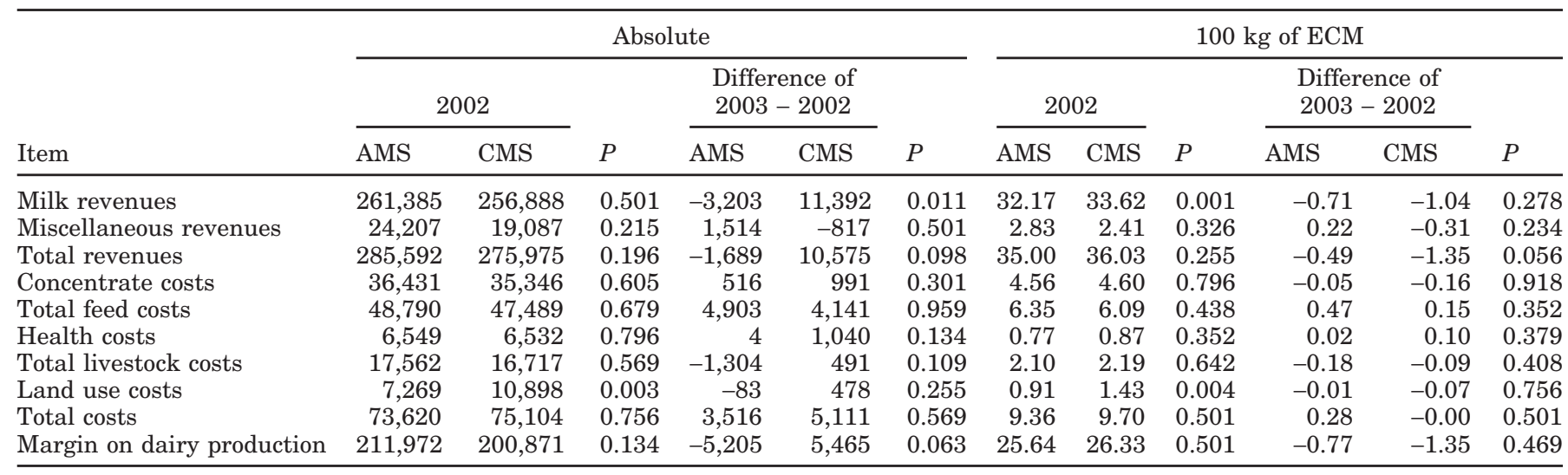


BIJL ET AL.

Table 7. Average gross margins, nonaccountable costs, and available for RDILP ${ }^{1}$ (in euros), absolute and per $100 \mathrm{~kg}$ of ECM, of 31 farms with an automatic milking system (AMS) and 31 farms with a conventional milking system (CMS) in 2003

\begin{tabular}{|c|c|c|c|c|c|c|}
\hline \multirow[b]{2}{*}{ Item } & \multicolumn{2}{|c|}{ Absolute } & \multirow[b]{2}{*}{$P$} & \multicolumn{2}{|c|}{$100 \mathrm{~kg}$ of ECM } & \multirow[b]{2}{*}{$P$} \\
\hline & AMS & CMS & & AMS & CMS & \\
\hline Margin on dairy production & 215,444 & 216,521 & 0.597 & 24.60 & 24.50 & 0.953 \\
\hline Gross margin & 231,542 & 232,519 & 0.754 & 26.51 & 26.34 & 0.938 \\
\hline Contractor & 21,783 & 15,361 & 0.004 & 2.55 & 1.81 & 0.003 \\
\hline Gas, water, electricity & 10,337 & 8,788 & 0.021 & 1.24 & 1.01 & 0.007 \\
\hline Maintenance and insurance of: & & & & & & \\
\hline Machinery and equipment & 28,088 & 24,411 & 0.136 & 3.15 & 2.72 & $\begin{array}{l}0.078 \\
0.122\end{array}$ \\
\hline Land, buildings, installations & 7,404 & 5,371 & 0.104 & 0.88 & 0.60 & 0.122 \\
\hline Total nonaccountable costs & 79,614 & 65,025 & 0.002 & 9.29 & 7.46 & 0.001 \\
\hline Available for RDILP & 151,928 & 167,494 & 0.046 & 17.22 & 18.87 & 0.046 \\
\hline
\end{tabular}

${ }^{1}$ Rent, depreciation, interest, labor, and profit.

portant factors in the financial results of a farm business, we chose a normative approach toward depreciation and interest of the milking system. The average purchase value of the AMS (including costs for the building) was estimated to be $€ 177,419$, with a yearly depreciation of $€ 15,968$, and a calculated average yearly interest of $€ 4,879$. This resulted in average total equipment costs for an AMS, excluding maintenance (which was part of the data described above), of $€ 20,847$. The average purchase value (including costs for the building) of a CMS was estimated to be $€ 78,210$. Estimated yearly depreciation and average yearly interest were estimated to be $€ 4,953$ and $€ 2,053$, respectively. Average total yearly costs for a CMS were $€ 7,006$. This was $€ 13,841$ less than the estimated yearly costs for an AMS. In this respect, it should be noted that the AMS in our study were not used to full capacity, negatively influencing the depreciation and interest costs. Moreover, although most economic studies (Cooper and Parsons, 1999; Arendzen and van Scheppingen, 2000; Hyde and Engel, 2002) use a shorter economic lifetime for an AMS, no reliable estimates exist on the economic life span of an AMS in comparison with a CMS. Because of the high-tech nature of the AMS, a shorter lifetime is assumed. However, this shorter lifetime may, in practice, be compensated for by a greater replacement rate of components of the AMS. The greater replacement rate of certain components can be found back in larger maintenance costs. In our study, we also found numerically greater maintenance costs for the AMS. The economic life span of the AMS is important because of its profitability relative to a CMS. If the economic life span of an AMS equaled that of a CMS, the difference in costs for depreciation and interest between the 2 systems would be $€ 8,518$ instead of $€ 13,841$. For future comparisons, it would be beneficial to gain more insight in the real economic life span of the AMS and CMS.

Given the present results, it is clear that profitability, in terms of money available for RDILP, is smaller in farms using an AMS. Moreover, farms with an AMS

Table 8. Average gross margins, nonaccountable costs, and available for RDILP ${ }^{1}$ (in euros), absolute and per $100 \mathrm{~kg}$ of ECM, of farms with an automatic milking system (AMS) and 16 farms with a conventional milking system (CMS) in 2002, and the differences in the structure of these farms between 2002 and 2003

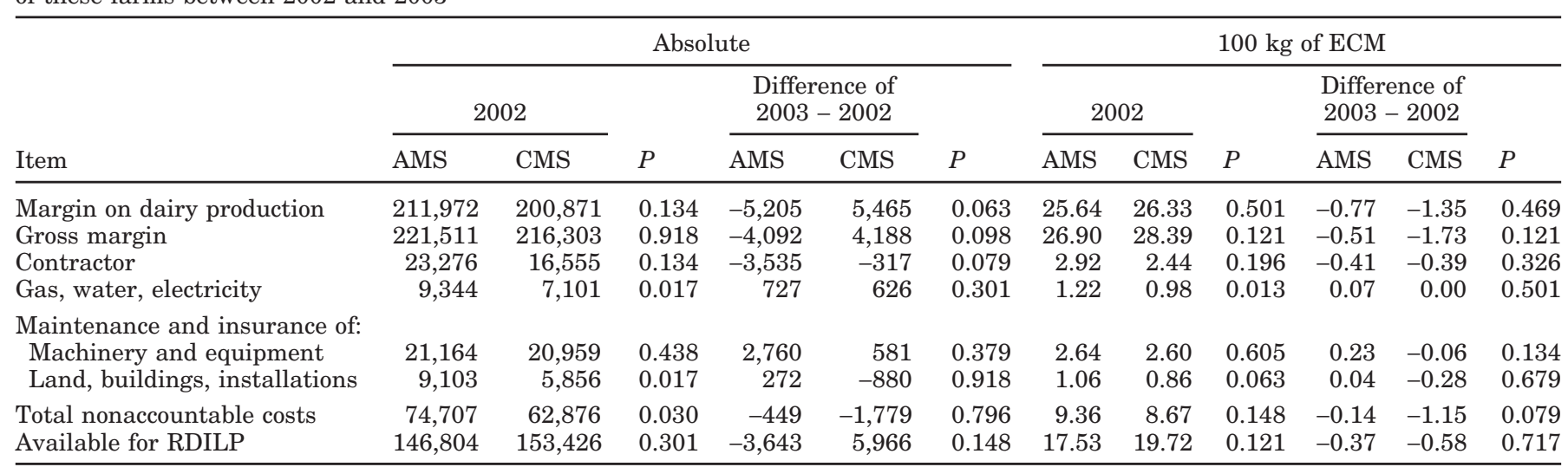

${ }^{1}$ Rent, depreciation, interest, labor, and profit. 
Table 9. Average revenues, costs, margin on dairy production, gross margin, and money available for RDILP ${ }^{1}$ expressed for full time equivalent for labor $(1 \mathrm{FTE}=2,540 \mathrm{~h})$ for the difference between automatic milking system (AMS) and conventional milking systems (CMS) for the year 2003 and the difference between the years 2002 and 2003 within system $(n=16)$

\begin{tabular}{|c|c|c|c|c|c|c|}
\hline \multirow[b]{3}{*}{ Item } & & & \multicolumn{4}{|c|}{ Milking system } \\
\hline & \multicolumn{2}{|c|}{ Milking system } & \multicolumn{2}{|c|}{ AMS } & \multicolumn{2}{|c|}{ CMS } \\
\hline & AMS & CMS & 2002 & 2003 & 2002 & 2003 \\
\hline No. of dairy farms & 31 & 31 & 16 & 16 & 16 & 16 \\
\hline Total revenues & 206,378 & $164,250^{\mathrm{a}}$ & 198,328 & 195,795 & 150,806 & 162,813 \\
\hline Total costs & 57,796 & 48,463 & 51,125 & 53,197 & 41,040 & 45,577 \\
\hline Margin on dairy production & 148,582 & $115,787^{\mathrm{a}}$ & 147,202 & 142,597 & 109,766 & 117,236 \\
\hline Gross margin & 163,056 & $127,939^{\mathrm{a}}$ & 156,861 & 152,516 & 119,482 & 127,264 \\
\hline Available for RDILP & 101,372 & 88,429 & 96,680 & 94,677 & 78,979 & $87,270^{\mathrm{b}}$ \\
\hline
\end{tabular}

${ }^{\text {a Different }}(P<0.05)$ from AMS.

${ }^{\mathrm{b}}$ Different $(P<0.05)$ from 2002 within a milking system.

${ }^{1}$ Rent, depreciation, interest, labor, and profit.

have larger depreciation and interest costs compared with farms using a CMS. This difference should be compensated for by using the amount of labor that has become available for the entrepreneur after installation of the milking robot. As calculated above, the maximum opportunity cost is, on average, $€ 21,840$ ( $1,092 \mathrm{~h}$ at a rate of $€ 20 / \mathrm{h}$ ). On average, this amount is insufficient to cover the increased costs of depreciation $(€ 13,841)$ and the smaller amount of money available for RDILP $(€ 15,566)$. This indicates that for many dairy farmers, adoption of an AMS system is more than just a purely economic decision, but a socioeconomic decision (Hogeveen et al., 2004; Mathijs, 2004).

\section{CONCLUSIONS}

Our study is the first economic comparison of an AMS vs. a CMS using actual farm data instead of models. Thus, our results are unique and worthwhile. Results showed that farms with an AMS used, on average, 29\% less (of their own) labor than farms using a CMS, whereas farms with a CMS grew more $(37,132-\mathrm{kg}$ milk quota and 5 dairy cows) than farms with an AMS (-3,756-kg milk quota and 0.5 dairy cows). Farms using a CMS had larger revenues ( $€ 7,899$ ), but farms with an AMS had smaller costs, especially livestock $(€ 2,354)$ and feeding costs $(€ 2,918)$. Therefore, no differences in the margin were detected between the 2 milking systems.

Fixed costs (excluding labor, depreciation, and interest) were larger for the AMS farms than for the CMS farms (€4,589). Larger fixed costs were caused by larger contractor costs $(€ 6,422)$ and costs for gas, water, and electricity $(€ 1,549)$. Because of these larger costs, the farms using a CMS had more money available for RDILP.
When expressed per FTE, the AMS farms had greater revenues, margins, and gross margins per FTE than the CMS farms. The AMS farms did have a numerically greater RDILP per FTE (€12,953) than did CMS farms. Although depreciation and interest were not available in our study, normative calculations showed larger depreciation and interest costs for the AMS. When deciding between investment in an AMS or a CMS, dairy farmers must weigh decreased labor needs for the AMS against increased fixed costs of milking with an AMS.

\section{ACKNOWLEDGMENTS}

We gratefully acknowledge Alfa Accountants en Adviseurs, in particular Jappie Rijpma, for providing the data used in this study and for fruitful discussions on the interpretation of results.

\section{REFERENCES}

Alfa, 2004. Data with a message: Analysis of dairy farming (in Dutch). Report. Alfa Accountants en Adviseurs, Wageningen, the Netherlands.

Arendzen, I., and A. T. J. van Scheppingen. 2000. Economical sensitivity of four main parameters defining the room for investment of automatic milking systems on dairy farms. Pages 201-211 in Robotic Milking, Proc. Int. Symp. H. Hogeveen and A. Meijering, ed. Wageningen Pers, Wageningen, the Netherlands.

Armstrong, D. V., and L. S. Daugherty. 1997. Milking robots in large dairy farms. Computers Electronics Agric. 17:123-128.

CBS. 2003. Dutch statistical data. http://www.cbs.nl Accessed June $20,2005$.

Cooper, K., and D. J. Parsons. 1999. An economic analysis of automatic milking using a simulation model. J. Agric. Eng. Res. 73:311-321.

de Koning, C. J. A. M., and W. Ouweltjes. 2000. Maximising the milking capacity of an automatic milking system. Pages 38-46 in Robotic Milking, Proc. Int. Symp. H. Hogeveen and A. Meijering, ed. Wageningen Pers, Wageningen, the Netherlands.

de Koning, K., and J. Rodenburg. 2004. Automatic milking: State of the art in Europe and North America. Pages 27-37 in Automatic Milking: A Better Understanding. A. Meijering, H. Hogeveen and 
C. J. A. M. de Koning, ed. Wageningen Academic Publishers, Wageningen, the Netherlands.

Dijkhuizen, A. A., R. B. M. Huirne, S. B. Harsh, and R. W. Gardner. 1997. Economics of robot application. Computers Electronics Agric. 17:111-121.

Field, A. 2000. Discovering Statistics Using SPSS for Windows: Advanced Techniques for the Beginner. Sage, London, UK.

Gustafsson, M. 2004. Working time studies in farms with conventional and automatic milking. Page 488 in Automatic Milking: A Better Understanding. A. Meijering, H. Hogeveen, and C. J. A. M. de Koning, ed. Wageningen Academic Publishers, Wageningen, the Netherlands.

Hemmer, J., B. Bosma, A. Everts, and I. Vermeij, ed. 2004. Quantitative Information on Animal Husbandry 2003-2004 (in Dutch). Res. Inst. Anim. Husbandry, Lelystad, the Netherlands.

Hogeveen, H., K. Heemskerk, and E. Mathijs. 2004. Motivations of Dutch farmers to invest in an automatic milking system or a conventional milking parlour. Pages 56-61 in Automatic Milking: A Better Understanding. A. Meijering, H. Hogeveen and C. J. A. M. de Koning, ed. Wageningen Academic Publishers, Wageningen, the Netherlands.

Hyde, J., and P. Engel. 2002. Investing in a robotic milking system: A Monte Carlo simulation analysis. J. Dairy Sci. 85:2207-2214.

Mathijs, E. 2004. Socio-economics aspects of automatic milking. Pages 46-55 in Automatic Milking: A Better Understanding. A. Meijering, H. Hogeveen and C. J. A. M. de Koning, ed. Wageningen Academic Publishers, Wageningen, the Netherlands.
Rotz, C. A., C. U. Coiner, and K. J. Soder. 2003. Automatic milking systems, farm size, and milk production. J. Dairy Sci. 86:41674177.

Sonck, B. R. 1995. Labor research on automatic milking with a human-controlled cow traffic. Neth. J. Agric. Sci. 43:261-285.

SPSS. 2005. SPSS for Windows Release 13.0. SPSS, Inc., Chicago, IL.

van 't Land, A., A. C. van Lenteren, E. van Schooten, C. Bouwmans, D. J. Gravesteyn, and P. Hink. 2000. Effects of husbandry systems on the efficiency and optimisation of robotic milking performance and managment. Pages 167-176 in Robotic Milking, Proc. Int. Symp. H. Hogeveen and A. Meijering, ed. Wageningen Pers, Wageningen, the Netherlands.

van Vugt, A. 2005. The backgrounds of production changes as a consequence of the introduction of an automatic milking system (in Dutch). MS Thesis, Wageningen Univ., Wageningen, the Netherlands.

Wade, K. M., M. A. P. M. van Asseldonk, P. B. M. Berentsen, W. Ouweltjes, and H. Hogeveen. 2004. Economic efficiency of automatic milking systems with specific emphasis on increases in milk production. Pages 63-67 in Automatic Milking: A Better Understanding. A. Meijering, H. Hogeveen, and C. J. A. M. de Koning, ed. Wageningen Academic Publishers, Wageningen, the Netherlands.

Wirtz, N., E. Tholen, H. Spiekers, W. Zähres, E. Pfeffer, and W. Trappmann. 2004. Vergleich zwischen automatischem und konventionellem melken im hinblick auf milchleistung und futteraufwand. Züchtugskunde 76:321-334. 